\title{
Serological detection and molecular characterization of piroplasmids in equids in Brazil
}

\author{
Maria Isabel Botelho Vieira ${ }^{\mathrm{a}, *}$, Márcio Machado Costa ${ }^{\mathrm{b}}$, Mateus Tonial de Oliveira ${ }^{\mathrm{c}}$, \\ Luiz Ricardo Gonçalves ${ }^{\mathrm{d}}$, Marcos Rogério Andrée ${ }^{\mathrm{e}}$, Rosangela Zacarias Machado ${ }^{\mathrm{e}}$ \\ ${ }^{a}$ Professor do Programa de Pós-Graduação em Bioexperimentação, UPF, Passo Fundo, RS, Brazil \\ ${ }^{\mathrm{b}}$ Professor do curso de Medicina Veterinária, UPF, Passo Fundo, RS, Brazil \\ ${ }^{c}$ Estudante de Mestrado do Programa de Pós-Graduação em Bioexperimentação da Universidade de Passo Fundo (UPF), Passo Fundo, RS, Brazil \\ d Estudante de Doutorado do Programa de Pós-Graduação em Microbiologia Agropecuária, UNESP, Jaboticabal, SP, Brazil \\ e Professor no Programa de Pós-Graduação em Medicina Veterinária e Microbiologia Agropecuária, UNESP, Jaboticabal, SP, Brazil
}

A R T I C L E I N F O

\section{Keywords:}

Equine piroplasmosis

Theileria equi

Babesia caballi

18S rRNA gene

Rio Grande do Sul

Brazil

\begin{abstract}
A B S T R A C T
Equine piroplasmosis is a disease caused by the hemoparasites Babesia caballi and Theileria equi and is considered to be the most important parasitic infection affecting Equidae. The objective of the present study was to carry out an epidemiological molecular and serological survey for the presence of these two protozoal organisms in equids from the northwestern region of the State of Rio Grande do Sul (RS), south Brazil. For this purpose, blood samples were collected from 90 equids in the city of Passo Fundo, RS, Brazil. Those were animals used for sport activities, outdoor recreational riding, and work including cattle herding and mounted patrol. Anti-T. equi and anti-B. caballi IgG antibodies were detected in the sera of those animals by commercial ELISA kits. The molecular diagnosis of equine piroplasmosis due to T. equi or B. caballi (or both) consisted in the amplification of the $18 \mathrm{~S}$ rRNA gene by nested PCR followed by sequencing of the amplified PCR product and sequence comparison and phylogenetic analysis of the isolates; 17 (18.9\%) and 5 (5.55\%) out of the 90 serum samples tested in this study were positive for T. equi and B. caballi, respectively. Piroplasmid 18S rRNA gene fragments were detected by PCR in $24.4 \%(22 / 90)$ of the samples analysed and shared $99-100 \%$ identity with sequences of T. equi by BLASTn. Samples for the phylogenetic analysis were divided into 2 groups. In group A, there was close phylogenetic relationship between 4 sequences and sequences previously reported along the US-Mexico border, in South Africa, and in Brazil. There was a phylogenetic proximity between 5 samples from group B and samples tested by other authors in the US and Spain. Variation of the 18S rRNA gene allowed the identification of 9 new $T$. equi genotypes in the geographical region studied.
\end{abstract}

\section{Introduction}

Equine piroplasmosis (EP) is caused by the hemoprotozoan parasites Babesia caballi (Nuttall and Strickland, 1912) and Theileria equi (Laveran, 1901) and is regarded as the most significant parasitic disease affecting the equine industry worldwide (Zobba et al., 2008). The World Organization for Animal Health (OIE) includes equine piroplasmosis in the list of notifiable diseases, and there are international traffic restrictions for equids infected with $T$. equi and B. caballi (OIE, 2017).

EP is transmitted by ticks of the Ixodidae family (Stiller et al., 2002) and iatrogenic transmission and intrauterine infections have also been reported (Getstenberg et al., 1999; Wise et al., 2013). EP is endemic in Asia and many parts of Europe, South and Central Americas and Africa
(OIE, 2014). In the year 2012, 30 countries reported the occurrence of EP (OIE, 2014).

Although A. cajennense sensu lato showed to be a competent intraestadial vector of $T$. equi (Scoles and Ueti, 2013), the transestadial transmission of $T$. equi by this tick species failed to be proved (Ribeiro et al., 2011; Scoles and Ueti, 2013). In Brazil, T. equi and B. caballi are mainly transmitted by Rhipicephalus (Boophilus) microplus and Anocentor nitens, respectively (Guimarães et al., 1998; Battsetseg et al., 2002; Kerber et al., 2009).

Brazil is considered endemic for T. equi infection (Heim et al., 2007) which prevalence varies according to how horses are raised in the area and which tick species are present in this particular zoogeographic region (Botteon et al., 2002).

The study of the genetic diversity of hemoparasite populations has

\footnotetext{
* Corresponding author at: Universidade de Passo Fundo, BR 285, Km 292, Passo Fundo, Rio Grande do Sul, 99052-900, Brazil.

E-mail address: marisabel@upf.br (M.I.B. Vieira).
} 
contributed to the understanding of the epidemiology of tick-borne diseases (Allsopp and Allsopp, 2006). Molecular tools have been employed to explore genetic structure and to assess epidemiological monitoring allowing researchers to analyse pathogen populations. For this reason, studies on the phylogenetic classification of $T$. equi have been carried out all over the world such as Spain, South Africa, USA, Korea and Brazil (Bhoora et al., 2009; Ferreira et al., 2016; Hall et al., 2013; Nagore et al., 2004; Seo et al., 2013).

The present study aimed to investigate the prevalence of anti-T. equi and anti-B. caballi antibodies in the serum of equids raised in the of the northwest region State of Rio Grande do Sul (RS), south Brazil, and to molecularly characterize the piroplasmid isolates that are present in this population.

\section{Materials and methods}

This study was approved by the Animal Experimentation Ethics Committee and Animal Care and Use Committee from the Federal University of Passo Fundo (UPF) (protocol 024/2014), Passo Fundo, RS, Brazil.

\subsection{Samples}

Between March and December 2014, blood samples were collected from 90 equids on 4 different premises [1-Inn (Horse Hotel), 2 - City Hall, 3 - Brigade, 4 - Veterinary Hospital of the University of Passo Fundo]. Passo Fundo ( $28^{\circ} 15^{\prime} 40^{\prime \prime} \mathrm{S}, 52^{\circ} 24^{\prime} 30^{\prime \prime} \mathrm{W}$ ) is a county in the northwest region of the State of Rio Grande do Sul (RS), south Brazil (Fig. 1). It is located $680 \mathrm{~m}$ above sea level, and includes fields and strips from the Atlantic Forest. The city has a humid subtropical climate, well-distributed rainfall all year round, hot summers, cold winters, and annual mean temperature of $17.5^{\circ} \mathrm{C}$ (Embrapa, 2017). This epidemiological survey was conducted in the following facilities: Inns (horse hotels) from different farms $(\mathrm{n}=30)$ where sampled horses had contact with cattle; Prefecture $(n=14)$ where animals were raised in the outskirts of the county; Brigade $(n=43)$ where horses from mounted patrol units were kept in a farm and grazed on native grass pastures; Veterinary Hospital $(n=3)$ which provided surgical and medical care to animals. At the time of collection of blood samples the animals had no ticks on their coat and were healthy and didn't show any clinical signs consistent with equine piroplasmosis.

Blood samples were collected from the jugular vein by venipuncture into vacuum blood collection tubes (Vacutainer) with and without EDTA. Serum was obtained by centrifuging blood samples at room temperature $\left(25^{\circ} \mathrm{C}\right)$ at $3000 \mathrm{rpm}$ for $10 \mathrm{~min}$. Serum samples were stored at $-20^{\circ} \mathrm{C}$ until the serological testing was performed. Collection tubes containing EDTA were stored at $-80^{\circ} \mathrm{C}$ for further DNA extraction.

\subsection{Enzyme-linked immunosorbent assay (ELISA) for equine piroplasmosis}

For the detection of IgG antibodies against T. equi and B. caballi, serum samples were tested with commercial ELISA kits (Imunodot Diagnostics, IMUNOTEST ${ }^{\circ}$ (specificity and sensitivity:100\%; 80\% and $84 \%$ for $T$. equi and B. caballi, respectively) according to the manufacturer's instructions. Briefly, $100 \mu \mathrm{L}$ of $T$. equi and B. caballi antigens (concentrations of $10 \mu \mathrm{g} / \mathrm{mL}$ and $2.5 \mu \mathrm{g} / \mathrm{mL}$, respectively), were diluted in a $0.05 \mathrm{M}$ sodium bicarbonate-carbonated buffer ( $\mathrm{pH}$ 9.6) and added to each well of a micro-ELISA plate (NunclonTM Surface; Nunc, Denmark). After incubation at $4{ }^{\circ} \mathrm{C}$ for $18 \mathrm{~h}$, the excess of antigen was removed by washing the plate with PBS Tween- 80 at $0.05 \%$. Uncoated sites in the wells were blocked by adding $200 \mu \mathrm{L}$ of PBS Tween- 80 containing $6 \%$ skim milk for $2 \mathrm{~h}$ at $37^{\circ} \mathrm{C}$. The blocking agent was

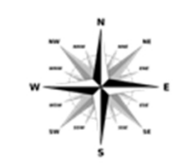

South America

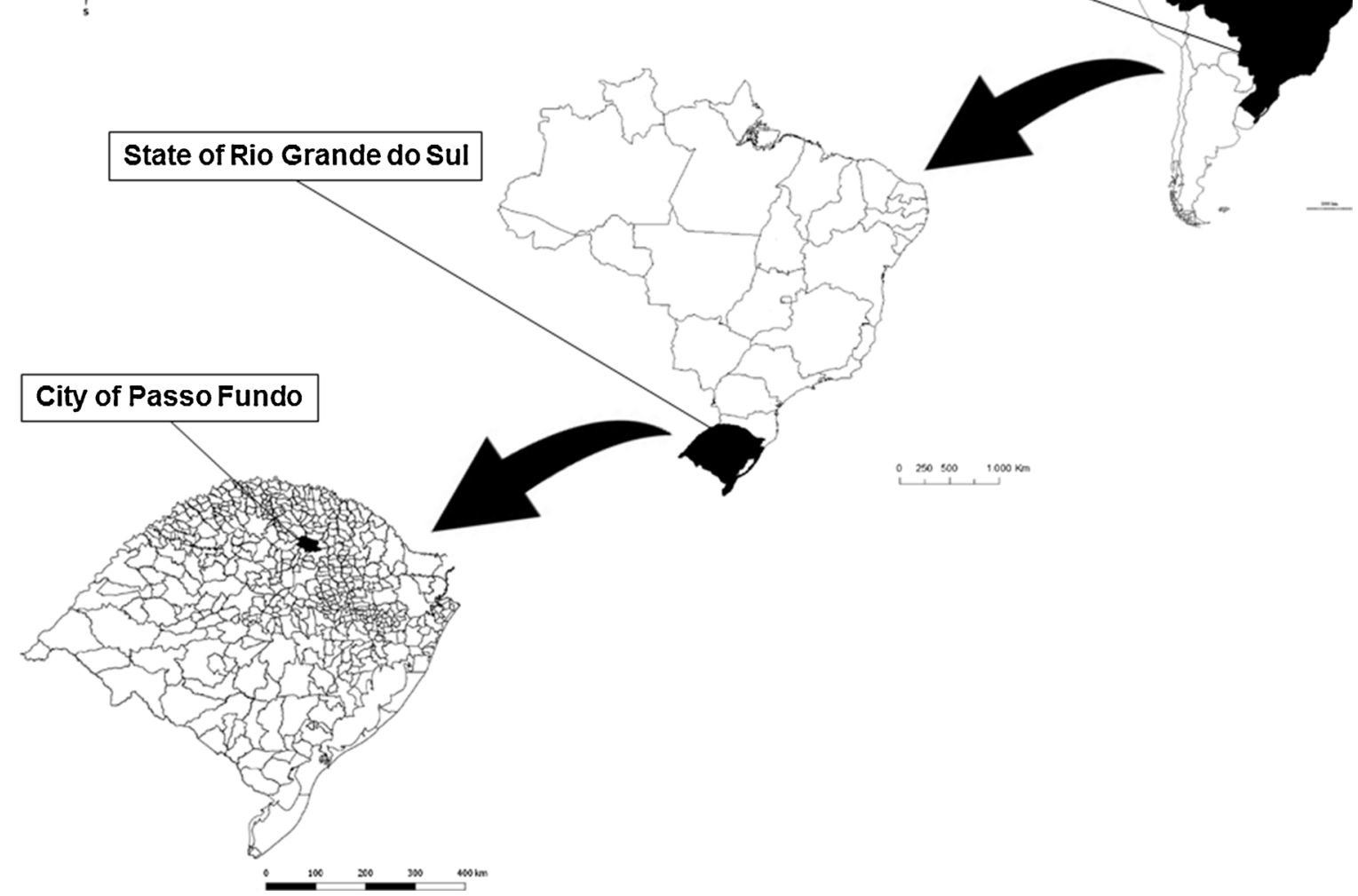

Fig. 1. Geographic location in the northwestern region of the State of Rio Grande do Sul (RS), southern Brazil, where equids were sampled in the present study. 
removed, the plate was washed with PBS Tween- 80 at $0.05 \%$, and individual equid sera diluted (1:100) in PBS Tween-80 with 5\% skim milk (PBS-TWSM) were added to each well and then incubated for $90 \mathrm{~min}$ at $37^{\circ} \mathrm{C}$. After washing the plates, $100 \mu \mathrm{L}$ of alkaline phosphatase antihorse IgG conjugated (Sigma-Aldrich, St. Louis, Missouri, USA) diluted 1:30.000 in PBS-TW-SM were added to each well and then incubated for $90 \mathrm{~min}$ at $37^{\circ} \mathrm{C}$. The plates were washed and the appropriate substrate ( $p$-Nitrophenyl phosphate) (Sigma-Aldrich, St. Louis, Missouri, USA) was added. Serum samples of donkeys from previous studies that tested positive or negative for equine piroplasmosis by ELISA were used in this study as known positive and negative controls in the ELISA assays (Machado et al., 2012). Absorbance at $405 \mathrm{~nm}$ was read after 45min incubation at room temperature using an ELISA reader (Dynex Technologies). The cut-off value ( 0.318 for both T. equi and B. caballi) was determined as being 2.5 times the mean absorbance value of negative controls, and readings above the cut-off value were considered positive according to (Machado et al., 1997).

\subsection{DNA extraction}

DNA was extracted from blood samples with EDTA using a QIAamp DNA Blood Mini kit (Qiagen, Hilden, Germany), according to the manufacturer's instructions.

\subsection{Molecular detection and characterization of T. equi e B. caballi}

Previously published conventional PCR protocols based on the $18 \mathrm{~S}$ rRNA gene (1600 bp) were used to amplify T. equi and B. caballi DNA (Bhoora et al., 2009) (Fig. 2). The primers (namely, NBabesia1F: 5'-AAGCCATGCATGTCTAAGTATAAGCTTTT-3' and 18SRev-TB: 5'GAATAATTCACCGGATCACTCG-3') were used for this purpose (Table 1). The reactions were performed using 5 microliters of DNA as a template in $25 \mu \mathrm{L}$ reaction mixtures containing 10X PCR buffer, $1.0 \mathrm{mM}$ $\mathrm{MgCl}_{2}, 0.8 \mathrm{mM}$ deoxynucleotide triphosphate (dNTPs) mixture, $1.0 \mathrm{U}$ Taq DNA Polymerase (Life Technologies, Carlsbad, CA, USA) and $0.5 \mu \mathrm{M}$ of each primer (Integrated DNA Technologies). PCR amplifications were performed by an initial cycle of $94^{\circ} \mathrm{C}$ for $2 \mathrm{~min}$ followed by 40 cycles of $94^{\circ} \mathrm{C}$ for $30 \mathrm{~s}, 60^{\circ} \mathrm{C}$ for $45 \mathrm{~s}$ and $72{ }^{\circ} \mathrm{C}$ for $1 \mathrm{~min}$, and a final extension of $72{ }^{\circ} \mathrm{C}$ for $7 \mathrm{~min}$. In addition, DNA samples were submitted to another $3 \mathrm{nPCR}$ assays in order to obtain the whole 18S rRNA gene fragment of $T$. equi and B. caballi. The amplification conditions were the same as previously described except for the annealing temperature (Table 1). DNA of T. equi and B. caballi from naturally infected donkeys were used as positive controls (Machado et al., 2012). Ultra-pure sterile water was used as the negative control in all PCR assays as detailed above. In order to avoid PCR contamination, DNA extraction, reaction

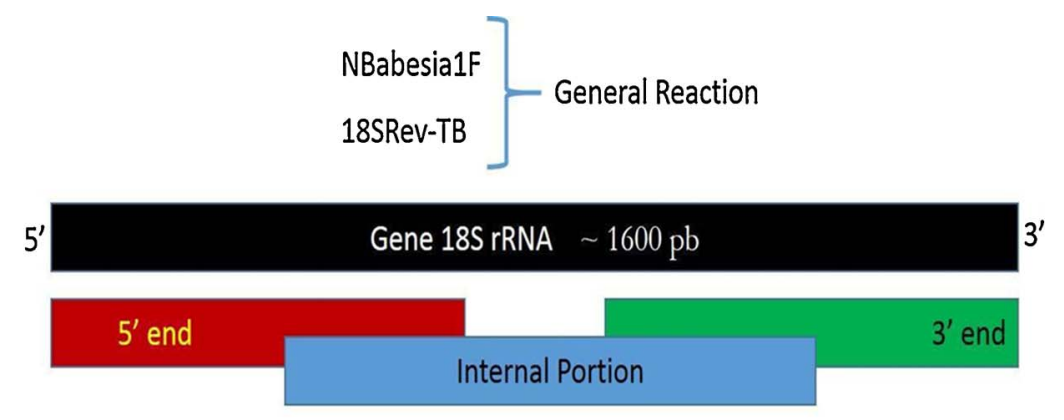

setup, PCR amplification and electrophoresis were performed in separated rooms. The gels were imaged under ultraviolet light using the Image Lab Software version 4.1 (Bio-Rad ${ }^{\circ}$ ). The amplified fragments of the expected size for each nested PCR assay were purified from the gel using Silica Bead DNA Gel Extraction Kit (Fermentas, São Paulo, SP, Brazil).

\subsection{Sequencing and phylogenetic analysis}

Amplicons obtained from nested PCR assays were sequenced in both directions using the same PCR primers (forward and reverse) by Sanger sequencing at (ABI Prism 310 Genetic Analyser-Applied Byosystem/ Perkin Elmer). Consensus sequences were obtained through analysis of the sense and antisense sequences using the CAP3 program (http:// mobyle.pasteur.fr/cgi-bin/MobylePortal/portal.py). Sequences deposited in the GenBank database were compared using the basic local alignment search tool (BLASTn) (Altschul et al., 1990). The sequences were aligned with sequences published in GenBank using Clustal/W (Thompson et al., 1994) and manually adjusted in Bioeditv.7.0.5.3 (Hall, 1999). Phylogenetic inference based on Maximum Likelihood criterion (ML) was inferred with RAxML-HPC BlackBox 7.6.3 (Stamatakis et al., 2005) through the CIPRES Science Gateway (Miller et al., 2011). Akaike information criterion (AIC) was used in Mega 5.05 to identify the most appropriate model of nucleotide substitution. GTRGAMMA + I model was chosen as the most appropriate for the Maximum Likelihood analysis of the 18S rRNA sequence alignment. The sequences amplified in the present study were deposited in the GenBank database under accession numbers: KU240064 to KU240072.

\subsection{Statistical analysis}

Descriptive statistics was used in the analysis of all data generated by serology and nPCR, and was expressed in absolute (total) and relative (percentage) frequencies. The software package SPSS ${ }^{\circ}$ Statistics version 20.0 was used to analyse the data.

\section{Results}

None of the equids included in this study presented clinical signs of piroplasmosis or were infested with ticks at the time of blood sampling. Seventeen (18.9\%) and 5 (5.55\%) horses were seropositive for T. equi and $B$. caballi, respectively (Table 2 ). Ten $(11.11 \%)$ equids were positive for T. equi by both ELISA and nPCR assays. Seven (7.8\%) animals were seropositive for T. equi by ELISA but negative in nPCR assays for this piroplasmid species (Table 3). On the other hand, 12 (13.33\%) animals were seronegative for T. equi by ELISA but positive for $T$. equi

Fig. 2. Nested PCR protocols based on the $18 \mathrm{~S}$ rRNA gene (1600 bp) used to amplify Theileria equi and Babesia caballi DNA, according to Bhoora et al. (2009).
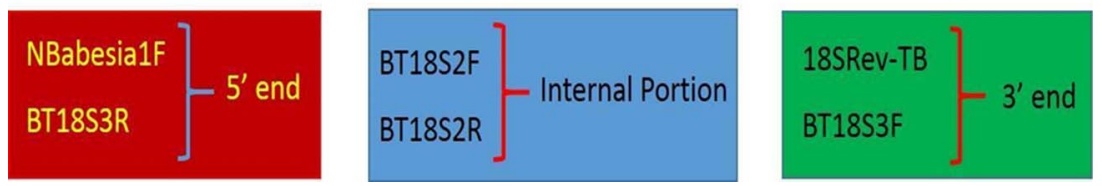
Table 1

Sequences of the primers used to amplify18S rRNA gene of equine piroplasmids.

\begin{tabular}{|c|c|c|c|c|}
\hline Primers & Reactions in PCR protocol & Oligonucleotide sequences $\left(5^{\prime}-3^{\prime}\right)$ & Anneling temperature & References \\
\hline NBabesia1F & $5^{\prime}$ end & AAGCCATGCATGTCTAAGTATAAGCTTTT & $58^{\circ} \mathrm{C}$ & Oosthuizen et al. (2008) \\
\hline BT18S3R & $5^{\prime}$ end & GAATAATTCACCGGATCACTCG & & Matjila et al. (2008) \\
\hline BT18S2F & Internal Portion & GGGTTCGATTCCGGAGAGGG & $55^{\circ} \mathrm{C}$ & Oosthuizen et al. (2008) \\
\hline BT18S2R & Internal Portion & CCCGTGTTGAGTCAAATTAAGCCG & & Matjila et al. (2008) \\
\hline BT18S3F & $3^{\prime}$ end & GGGCATTCGTATTTAACTGTCAGAGG & $55^{\circ} \mathrm{C}$ & Oosthuizen et al. (2008) \\
\hline 18SRev-TB & $3^{\prime}$ end & CCTCTGACAGTTAAATACGAATGCCC & & Bhoora et al. (2009) \\
\hline
\end{tabular}

Table 2

Serological and molecular prevalence of $T$. equi and B. caballi in equids from southern Brazil.

\begin{tabular}{|c|c|c|c|}
\hline & $\begin{array}{l}\text { ELISA for Theileria } \\
\text { equi }\end{array}$ & $\begin{array}{l}\text { ELISA for Babesia } \\
\text { caballi }\end{array}$ & $\begin{array}{l}\text { nPCR for Theileria } \\
\text { equi }\end{array}$ \\
\hline Positive & 17 (18.9\%) & $5(5.6 \%)$ & $22(24.4 \%)$ \\
\hline Negative & $73(81.1 \%)$ & $85(94.4 \%)$ & $68(75.6 \%)$ \\
\hline Total & $90(100 \%)$ & $90(100 \%)$ & $90(100 \%)$ \\
\hline
\end{tabular}

Table 3

Comparison between the results of ELISA and nPCR assays for T. equi in equids from southern Brazil.

\begin{tabular}{|c|c|c|c|}
\hline & \multicolumn{2}{|c|}{ ELISA Theileria equi } & \multirow[t]{2}{*}{ Total } \\
\hline nPCR Theileria equi & Positive & Negative & \\
\hline Positive & $10(11.1 \%)$ & $12(13.3 \%)$ & $22(24.4 \%)$ \\
\hline Negative & $7(7.8 \%)$ & $61(67.8 \%)$ & $68(75.6 \%)$ \\
\hline Total & $17(18.9 \%)$ & $73(81.1 \%)$ & $90(100.0 \%)$ \\
\hline
\end{tabular}

Table 4

Comparison between the results found in ELISA tests for B. caballi and T. equi in equids southern Brazil.

\begin{tabular}{|c|c|c|c|}
\hline \multirow[b]{2}{*}{ ELISA Theileria equi } & \multicolumn{2}{|c|}{ ELISA Babesia caballi } & \multirow[t]{2}{*}{ Total } \\
\hline & Positive & Negative & \\
\hline Positive & $2(2.2 \%)$ & $15(16.7 \%)$ & $17(18.9 \%)$ \\
\hline Negative & $3(3.3 \%)$ & $70(77.8 \%)$ & $73(81.1 \%)$ \\
\hline Total & $5(5.6 \%)$ & $85(94.4 \%)$ & $90(100.0 \%)$ \\
\hline
\end{tabular}

Table 5

Comparison between the results of ELISA for B. caballi and nPCR assays for T. equi in equids from southern Brazil.

\begin{tabular}{|c|c|c|c|}
\hline \multirow[b]{2}{*}{ nPCR Theileria equi } & \multicolumn{2}{|c|}{ ELISA Babesia caballi } & \multirow[t]{2}{*}{ Total } \\
\hline & Positive & Negative & \\
\hline Positive & $1(1.1 \%)$ & $21(23.3 \%)$ & $22(24.4 \%)$ \\
\hline Negative & $4(4.4 \%)$ & $64(71.1 \%)$ & $68(75.6 \%)$ \\
\hline Total & $5(5.6 \%)$ & $85(94.4 \%)$ & $90(100.0 \%)$ \\
\hline
\end{tabular}

by nPCR. Additionally, $2(2.22 \%)$ animals were seropositive for both $T$. equi and B. caballi (Table 4). One (1.11\%) animal was positive for both $T$. equi by nPCR and B. caballi by ELISA but seronegative for T. equi (Table 5).

Among all equid DNA samples that were analysed, 24.4\% (22/90) were positive for equine piroplasms in $18 \mathrm{~S}$ rRNA-based nPCR assays. All 22 sequences shared identities ranging between $99 \%$ and $100 \%$ with $T$. equi isolates previously detected by other researchers by BLASTn analysis in the USA and on the US-Mexico border (Table 6). B. caballi DNA was not detected in any of the samples sequenced. Additionally, 9 sequences were submitted to phylogenetic analysis based on a $1600 \mathrm{pb}$ $18 \mathrm{~S}$ rRNA gene fragment, since that the amplification of all three $18 \mathrm{~S}$ rRNA fragments (5', inner and $3^{\prime}$ regions) was not achieved in 13 samples
The sequences were included into 3 major groups (\#1, \#2 and \#3), which were then subdivided into 9 clusters (A-H) (Fig. 3). Among the 9 sequences amplified, 2 clustered with other 2 T. equi sequences previously detected in equids in the State of Rio de Janeiro (RJ), southeast Brazil, and with 1 sequence reported by other authors in South Africa, forming Group 1, cluster C; 2 sequences were positioned near the T. equi sequence previously detected in a horse on the USA-Mexico border, establishing Group 1; cluster E; 5 sequences, belonging to Group 3 and cluster I, were closely related to T. equi isolates previously detected in the USA, Spain, South Africa, and Brazil (Fig. 3).

\section{Discussion}

The use of serological tests such as ELISA has been recommended for the diagnosis of equine piroplasmosis. Serologic surveillance would prevent seropositive animals from entering piroplasmosis-free countries such as the US, Canada, Australia, Japan, and New Zealand (Brüning, 1996). In the present study, $18.9 \%$ and $5.55 \%$ of equids were seroreactive for $T$. equi and $B$. caballi, respectively. Previous serosurveys of horses for antibodies to T. equi and B. caballi in south Brazil have shown prevalence rates for $T$. equi ranging between $31.6 \%$ and $46.25 \%$ (Dall'Agnol et al., 2013; Golynski et al., 2008).

The results of previous seroprevalence surveys for equine piroplasmosis carried out in Brazil show that in those regions of the country that are considered endemic for the disease such as the State of Minas Gerais (MG), southeast Brazil, the frequency of serum antibodies against $T$. equi and B. caballi ranges between $83 \%$ and $91 \%$, respectively (Heim et al., 2007). On the other hand, in the city of Jaboticabal, State of São Paulo (SP), southeast Brazil, 100\% of the horses tested were seropositive for T. equi (Baldani et al., 2010). In Orlândia county, state of São Paulo (SP), southeast Brazil, $73.8 \%$ and $93.2 \%$ of the serum samples from donkeys were positive for $T$. equi and $B$. caballi, respectively. In the State of Paraná (PR), south Brazil, $61 \%$ of the animals were seropositive for $T$. equi in a study population of 400 horses (Prochno et al., 2014). In the State of Rio Grande do Sul (RS), Brazil, blood samples from 108 mares were collected in a premise located in the south of the state; $22 \%$ and $15 \%$ of these samples were positive for T. equi by Indirect Immunofluorescent Test (IFAT) and by nPCR, respectively (Nizoli et al., 2008).

Although equids from the study population were asymptomatic, animals from the Horse Hotel, the Brigade, and the City Hall were seropositive for $T$. equi or B. caballi (or both) or the 18S rRNA gene was PCR-amplified. These results are epidemiologically relevant as they reinforce the fact that asymptomatic, infected carriers are possibly the source of infection for tick vectors, perpetuating piroplasms in equine populations.

In the present epidemiological survey, 7 horses were positive for $T$. equi by ELISA and negative for $T$. equi by nPCR. Those are possibly carrier animals chronically infected with the piroplasm and in which the parasitemia is below the detection threshold of molecular diagnostic techniques. A low-grade, long-lasting parasitemia would stimulate the immune system in animals maintaining antibodies in serum at detectable levels. On the other hand, induction of a protective antibody response in animals previously exposed to T. equi and that cleared the infection is a possibility that should also be considered. T. equi DNA was 
Table 6

Nine isolates of equine piroplasms whose 18S rRNA sequences were used in phylogenetic analysis according to their location, host and GenBank accession number.

\begin{tabular}{|c|c|c|c|c|c|}
\hline Samples & Accession Number & Animals & $\%$ Identity & Genotype & References \\
\hline Isolate 02 & KU240064 & Female horse & 99 & JX177670 Texas - USA & Hall et al. (2013) \\
\hline Isolate04 & KU240065 & Female horse & 99 & JX177673 Texas - USA & Hall et al. (2013) \\
\hline Isolate13 & KU240066 & Male horse & 99 & JQ390047 USA-Mexico & Hall et al. (2013) \\
\hline Isolate19 & KU240067 & Female horse & 100 & JQ390047 USA-Mexico & Hall et al. (2013) \\
\hline Isolate 20 & KU240068 & Male horse & 100 & JX177670 Texas - USA & Hall et al. (2013) \\
\hline Isolate 22 & KU240069 & Female horse & 99 & CP001669 - USA & Kappmeyer et al. (2012) \\
\hline Isolate35 & KU240070 & Male horse & 99 & JQ390047 USA-Mexico & Hall et al. (2013) \\
\hline Isolate 41 & KU240071 & Male Horse & 100 & JQ390047 USA-Mexico & Hall et al. (2013) \\
\hline Isolate43 & KU240072 & Female horse & 99 & CP001669 - USA & Kappmeyer et al. (2012) \\
\hline
\end{tabular}

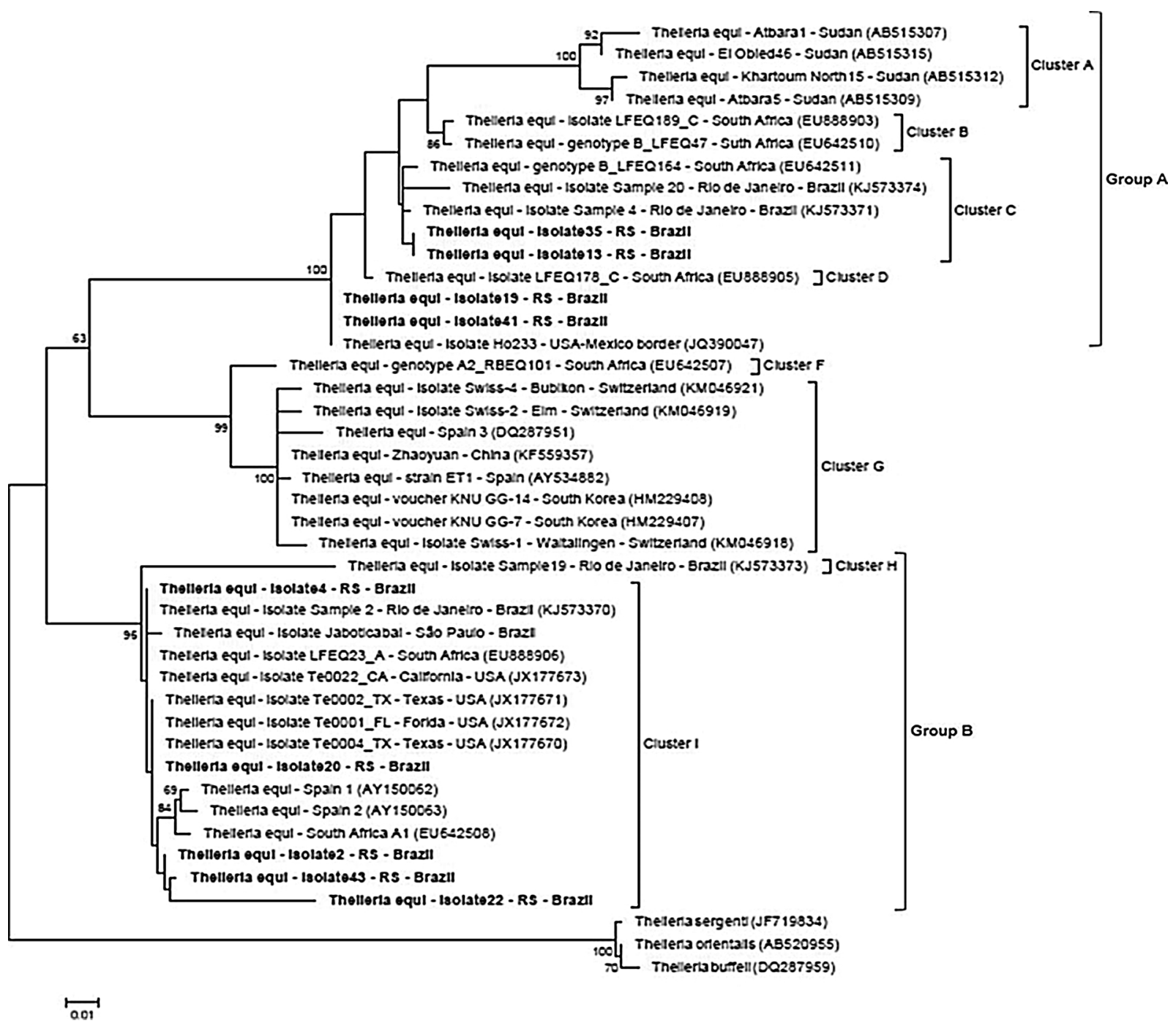

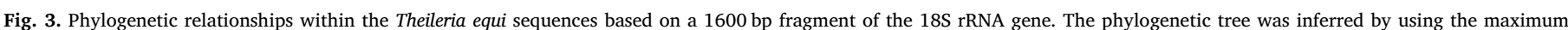

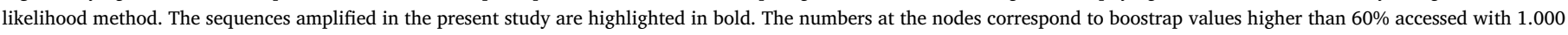
replicates. Theileria species was used as outgroup. RS: Rio Grande do Sul.

detected by PCR in blood samples from 12 animals that had no antibodies against this piroplasm in serum tested by ELISA. These are probably cases of recent infection in which there was not enough time to allow the animals to mount an effective immune response with the production of detectable levels of antibodies to T. equi. In this respect, horses experimentally infected with $T$. equi and B. caballi take from 3 to 20 days to produce antibodies against these piroplasms.

With regard to $B$. caballi infection, one of the seropositive animals was a donkey originally from the city of Sorocaba, State of Sao Paulo (SP), southeast Brazil, that was relocated to the city of Passo Fundo,
State of Rio Grande do Sul (RS), southern Brazil. Anocentor nitens, the vector for B. caballi, occurs in pastures in Sorocaba (Martins et al., 2015). Indeed, both T. equi and B. caballi and their vectors (Machado et al., 2012) are well distributed in the state of Sao Paulo, from where the referred pony was transferred. One pony and three horses from the Brigade, all born and raised in the State of Rio Grande do Sul (RS), southern Brazil, were also seropositive for piroplasms. In our study, a small number of serum samples were positive for $B$. caballi by ELISA. This low number of $B$. caballi positive samples could stem from the fact that tick vectors, such as $A$. nitens, are not present in the studied area 
(IPVDF, 2013). Therefore, the search for additional tick vectors and other routes of transmission for $B$. caballi in the state of Rio Grande do Sul is much needed in order to better understand the prevalence and epidemiology of equine piroplasmosis in the area.

Despite the fact that equine piroplasmosis is a disease of worldwide importance due to growing international trade of livestock and high intercontinental movement of horses (Nicolaiewsky et al., 2001), information about the epidemiology of this parasitic disease affecting equids in different countries is scarce. In recent years, major advances in diagnostic molecular biology have allowed the identification of several genotypes of Theileria and Babesia in Equidae (Bhoora et al., 2009; Nagore et al., 2004). In the present study, T. equi 18S rRNA gene was PCR-amplified in $24.4 \%$ (22/90) of the blood samples tested. Heim et al. (2007), when conducted a study on piroplasmosis in a population of horses from slaughterhouses in southeast Brazil, found that $59.7 \%$ of the blood samples were positive for $T$. equi based on the amplification of a fragment of the T. equi EMA-1 gene.

The 18S rRNA gene has been successfully used for the molecular characterization of equine piroplasmids. Besides, new genotypes of equine piroplasmids have been identified in several regions around the world using this approach (Bhoora et al., 2009; Munkhjargal et al., 2013; Qablan et al., 2013). The present study showed that some genotypes clustered with 18S rRNA sequences belonging to other two genotype groups previously reported (Bhoora et al., 2009). Moreover, as opposed to a previous study (Heim et al., 2007) performed in different geographical regions in Brazil in which no sequence variation was detected in the EMA-1 and RAP-1 genes within T. equi and $B$. caballi, respectively, the PCR-amplified sequences from equids in the State of Rio Grande do Sul (RS) were grouped into different clusters and groups. The genetic variation found in T. equi $18 \mathrm{~S}$ rRNA sequences in the present study and in other previous studies (Ketter-Ratzon et al., 2017; Ros-García et al., 2013; Salim et al., 2010) could be due to the introduction of infected animals into a herd (Salim et al., 2010) and/or sexual reproduction of piroplasms in tick vectors (Bhoora et al., 2009).

Herein, phylogenetic analysis showed that $T$. equi genotypes detected in horses in Brazil do not seem to be geographically restricted, since genotypes detected in animals sampled in different states, namely São Paulo and Rio de Janeiro, clustered together.

The high genetic diversity in T. equi $18 \mathrm{~S}$ rRNA sequences (Bhoora et al., 2009; Qablan et al., 2013) suggest the presence of new Theileria species in equine populations. However, a recent study evaluated several 18S rRNA sequences positioned in different groups showing that the average divergence of paired sequences between groups (B and E) was 0.01 and therefore shared $99 \%$ identity to one another (KetterRatzon et al., 2017). Although it is difficult to determine where genetic diversity ends and a new species starts, a multifactorial approach including 18S rRNA analysis, multilocus sequence typing (MLST), full genome analysis and ecological factors could help delineate new Theileria species.

Since the study area is considered a strong market for breeding, raising and buying/selling of horses with frequent relocation/movement of animals between different regions of the country and exportation/importation of animals with new additions into herds, the data generated by this epidemiological survey would be useful for the establishment of preventive measures and implementation of disease control programs where animals are exported to other countries or participate in equestrian events.

\section{Conclusion}

Serological and molecular diagnostic tests are important tools to study the epidemiology of equine piroplasmosis. The results of the present survey show that $T$. equi is the main causative agent of equine piroplasmosis in Passo Fundo, RS, Brazil.

Using a phylogenetic approach, 9 different $T$. equi genotypes were identified for the first time in Equidae in south Brazil. These findings confirm the hypothesis that a large genetic diverstity of piroplasms exist. However, additional studies must be carried out in order to better understand the importance of such diversity in the epidemiology of equine piroplasmosis.

\section{Declaration of interest}

The authors declare no actual or potential conflict of interest including any financial, personal or other relationships with other people or organizations within three years of beginning the submitted work that could inappropriately influence, or be perceived to influence our work.

\section{Acknowledgements}

The authors would like to thank the staff of the Immunoparasitology Laboratory from the Paulista State University Júlio de Mesquita Filho (UNESP), Jaboticabal, SP, Brazil, for their help and commitment during this study. We also thank the financial support of the Coordination for the Improvement of Higher Education Personnel (CAPES) from the Federal Government of Brazil.

\section{References}

Allsopp, M.T., Allsopp, B.A., 2006. Molecular sequence evidence for the reclassification of some Babesia species. Ann. N. Y. Acad. Sci. 1081, 509-517.

Altschul, S.F., Gish, W., Miller, W., Myers, E.W., Lipman, D.J., 1990. Basic local alignment search tool. J. Mol. Biol. 215, 403-410.

Baldani, C.D., Nakaghi, A.C.H., Machado, R.Z., 2010. Occurrence of Theileria equi in horses raised in the Jaboticabal microregion, São Paulo State, Brazil. Rev. Bras. Parasitol. Vet. 19, 228-232.

Battsetseg, B., Lucero, S., Xuan, X., Claveria, F.G., Inoue, N., Alhassan, A., Kanno, T., Igarashi, I., Nagasawa, H., Mikami, T., 2002. Detection of natural infection of Boophilus microplus with Babesia equi and Babesia caballi in Brazilian horses using nested polymerase chain reaction. Vet. Parasitol. 107, 351-357.

Bhoora, R., Franssen, L., Oosthuizen, M.C., Guthrie, A.J., Zweygarth, E., Penzhorn, B.L., Jongejan, F., Collins, N.E., 2009. Sequence heterogeneity in the 18S rRNA gene within Theileria equi and Babesia caballi from horses in South Africa. Vet. Parasitol. $159,112-120$.

Botteon, P.d.T.L., Massard, C.L., Botteon, R.D.C., Loss, Z.G., Linhares, G.F., 2002. Seroprevalencia de Babesia equi en tres diferentes sistemas de crianza de equinos: Rio de Janeiro-Brasil. Parasitol. Latinoam. 57, 141-145.

Brüning, A., 1996. Equine piroplasmosis an update on diagnosis, treatment and prevention. Br. Vet. J. 152, 139-151.

Dall'Agnol, B., Dau, S.L., Webster, A., Alves, L.P., Vivan, C.C., Gauger, A.L., Vieira, M.I.B., Rodrigues, R.O., Martins, J.R., Klafke, G.M., Reck, J., 2013. Soroprevalência de Theileria equi em equinos do município de Passo Fundo, RS. In: IV Simpósio Brasileiro de Acarologia. Bento Gonçalves - RS.

Embrapa, 2017. Clima de Passo Fundo.

Ferreira, E.P., Vidotto, O., Almeida, J.C., Ribeiro, L.P., Borges, M.V., Pequeno, W.H., Stipp, D.T., de Oliveira, C.J., Biondo, A.W., Vieira, T.S., 2016. Serological and molecular detection of Theileria equi in sport horses of northeastern Brazil. Comp. Immunol. Microbiol. Infect. Dis. 47, 72-76.

Getstenberg, C., Allen, W.R., Phipps, L.P., 1999. Mechanical transmission of Babesia equi infection in a British herd of horses. In: Proceedings of the Eight International Conference on Equine Infectious Diseases. Dubai. pp. 217-222.

Golynski, A., Fernandes, K., Baldani, C., Golynski, A., Madeiro, A., Machado, R., Botteon, P.T., Massard, C., 2008. Seroepidemiological studies on Babesia equi in horses from the State of Rio Grande do Sul determined by indirect immunoflourecence test and Elisa. Rev. Bras. Parasitol. Vet. 17, 317-321.

Guimarães, A., Lima, J., Ribeiro, M., 1998. Sporogony and experimental transmission of Babesia equi by Boophilus microplus. Parasitol. Res. 84, 323-327.

Hall, C.M., Busch, J.D., Scoles, G.A., Palma-Cagle, K.A., Ueti, M.W., Kappmeyer, L.S., Wagner, D.M., 2013. Genetic characterization of Theileria equi infecting horses in North America: evidence for a limited source of US introductions. Parasit. Vectors $6,1$.

Hall, T.A., 1999. BioEdit: a user-friendly biological sequence alignment editor and analysis program for Windows 95/98/NT. Nucleic Acids Symposium Series. pp. 95-98.

Heim, A., Passos, L.M., Ribeiro, M.F., Costa-Júnior, L.M., Bastos, C.V., Cabral, D.D., Hirzmann, J., Pfister, K., 2007. Detection and molecular characterization of Babesia caballi and Theileria equi isolates from endemic areas of Brazil. Parasitol. Res. 102, 63-68.

IPVDF, 2013. Sumarização dos registros de espécies e hospedeiros para material do Rio Grande do Sul da COLEÇÃO DE CARRAPATOS do Laboratório de Parasitologia do IPVDF. http://www.ipvdf.rs.gov.br/upload/1425478470_atualizacao_do_acervo_de carrapatos_do_ipvdf.pdf (Accessed 4 December 2017).

Kappmeyer, L.S., Thiagarajan, M., Herndon, D.R., Ramsay, J.D., Caler, E., Djikeng, A. Gillespie, J.J., Lau, A.O., Roalson, E.H., Silva, J.C., Silva, J.M., Suarez, C.E., Ueti, 
M.W., Nene, V.M., Mealey, R.H., Knowles, D.P., Brayton, K.A., 2012. Comparative genomic analysis and phylogenetic position of Theileria equi. BMC Genomics 13 , $1-12$.

Kerber, C.E., Labruna, M.B., Ferreira, F., De Waal, D.T., Knowles, D.P., Gennari, S.M., 2009. Prevalence of equine Piroplasmosis and its association with tick infestation in the State of São Paulo, Brazil. Rev. Bras. Parasitol. Vet. 18, 1-8.

Ketter-Ratzon, D., Tirosh-Levy, S., Nachum-Biala, Y., Saar, T., Qura'n, L., Zivotofsky, D., Abdeen, Z., Baneth, G., Steinman, A., 2017. Characterization of Theileria equi genotypes in horses in Israel, the Palestinian Authority and Jordan. Ticks Tick Borne Dis. 8 (4), 499-505.

Laveran, A., 1901. Contribution a l'etude de Piroplasma equi. CR. Soc. Biol. 53, 385-388.

Machado, R., Montassier, H., Pinto, A., Lemos, E., Machado, M., Valadão, I., Barci, L. Malheiros, E., 1997. An enzyme-linked immunosorbent assay (ELISA) for the detection of antibodies against Babesia bovis in cattle. Vet. Parasitol. 71, 17-26.

Machado, R., Toledo, C., Teixeira, M., André, M., Freschi, C., Sampaio, P., 2012. Molecular and serological detection of Theileria equi and Babesia caballi in donkeys (Equus asinus) in Brazil. Vet. Parasitol. 186, 461-465.

Martins, T.F., Teixeira, R.H.F., Labruna, M.B., 2015. Ocorrência de carrapatos em animais silvestres recebidos e atendidos pelo Parque Zoológico Municipal Quinzinho de Barros, Sorocaba, São Paulo, Brasil. Braz. J. Vet. Res. An. Sci. 52, 319-324.

Matjila, P.T., Leisewitz, A.L., Oosthuizen, M.C., Jongejan, F., Penzhorn, B.L., 2008. Detection of a Theileria species in dogs in South Africa. Vet. Parasitol. 157, 34-40.

Miller, M.A., Pfeiffer, W., Schwartz, T., 2011. The CIPRES science gateway: a community resource for phylogenetic analyses. Proceedings of the 2011 TeraGrid Conference: Extreme Digital Discovery 41.

Munkhjargal, T., Sivakumar, T., Battsetseg, B., Nyamjargal, T., Aboulaila, M., Purevtseren, B., Bayarsaikhan, D., Byambaa, B., Terkawi, M.A., Yokoyama, N., 2013. Prevalence and genetic diversity of equine piroplasms in Tov province, Mongolia. Infect. Genet. Evol. 16, 178-185.

Nagore, D., García-Sanmartín, J., Garcia-Pérez, A.L., Juste, R.A., Hurtado, A., 2004. Detection and identification of equine Theileria and Babesia species by reverse line blotting: epidemiological survey and phylogenetic analysis. Vet. Parasitol. 123, 41-54.

Nicolaiewsky, T.B., Richter, M.F., Lunge, V.R., Cunha, C.W., Delagostin, O., Ikuta, N., Fonseca, A.S., Da Silva, S.S., Ozaki, L.S., 2001. Detection of Babesia equi (Laveran, 1901) by nested polymerase chain reaction. Vet. Parasitol. 101, 9-21.

Nizoli, L.Q., Götze, M.M., Félix, S.R., Da Silva, S.S., Nogueira, C.E.W., 2008. Frequency of seropositive equines for Theileria equi in the southern rio grande do sul state, Brazil. Parasitol. Latinoam. 63, 46-50.

Nuttall, G.H., Strickland, C., 1912. On the occurrence of two species of parasites in equine piroplasmosis or biliary fever. Parasitology 5, 65-96.

OIE, 2014. Chapter 2.5.8. Equine Piroplasmosis. Terrestrial Manual. World Organisation for Animal Health. http://www.oie.int/fileadmin/Home/eng/Health_standards/
tahm/2.05.08_EQUINE_PIROPLASMOSIS.pdf. (Accessed 4 december 2017).

OIE, 2017. Capítulo 12.7. Piroplasmose equina. Código Sanitario para los Animales Terrestres. World Organisation for Animal Health. http://www.oie.int/fileadmin/ Home/esp/Health_standards/tahc/current/chapitre_equine_piroplasmosis.pdf (Accessed 4 december 2017).

Oosthuizen, M.C., Zweygarth, E., Collins, N.E., Troskie, M., Penzhorn, B.L., 2008. Identification of a novel Babesia sp. from a sable antelope (Hippotragus niger Harris, 1838). J. Clin. Microbiol. 46, 2247-2251.

Prochno, H.C., Scorsin, L.M., De Melo, F.R., Baldani, C.D., Falbo, M.K., Aquino L.C.T. d. Lemos, K.R., 2014. Seroprevalence rates of antibodies against Theileria equi in team roping horses from central-western region of Paraná. Rev. Bras. Parasitol. Vet. 23, 85-89.

Qablan, M.A., Obornik, M., PetrželkovÁ, K.J., Sloboda, M., Shudiefat, M.F., HořÍn, P., Lukeš, J., ModrÝ, D., 2013. Infections by Babesia caballi and Theileria equi in Jordanian equids: epidemiology and genetic diversity. Parasitology 140, 1096-1103.

Ribeiro, M.F., da Silveira, J.A., Bastos, C.V., 2011. Failure of the Amblyomma cajennense nymph to become infected by Theileria equi after feeding on acute or chronically infected horses. Exp. Parasitol. 128, 324-327.

Ros-García, A., M'ghirbi, Y., Hurtado, A., Bouattour, A., 2013. Prevalence and genetic diversity of piroplasm species in horses and ticks from Tunisia. Infect. Genet. Evol. $17,33-37$.

Salim, B., Bakheit, M.A., Kamau, J., Nakamura, I., Sugimoto, C., 2010. Nucleotide sequence heterogeneity in the small subunit ribosomal RNA gene within Theileria equi from horses in Sudan. Parasitol. Res. 106, 493.

Scoles, G.A., Ueti, M.W., 2013. Amblyomma cajennense is an intrastadial biological vector of Theileria equi. Parasit. Vectors 6, 306.

Seo, M.-G., Yun, S.-H., Choi, S.-K., Cho, G.-J., Park, Y.-S., Cho, K.-H., Kwon, O.-D., Kwak, D., 2013. Molecular and phylogenetic analysis of equine piroplasms in the Republic of Korea. Res. Vet. Sci. 94, 579-583.

Stamatakis, A., Ludwig, T., Meier, H., 2005. RAxML-III: a fast program for maximum likelihood-based inference of large phylogenetic trees. Bioinformatics 21, 456-463.

Stiller, D., Goff, W.L., Johnson, L.W., Knowles, D.P., 2002. Dermacentor variabilis and Boophilus microplus (Acari: ixodidae): experimental vectors of Babesia equi to equids. J. Med. Entomol. 39, 667-670.

Thompson, J.D., Higgins, D.G., Gibson, T.J., 1994. CLUSTAL W: improving the sensitivity of progressive multiple sequence alignment through sequence weighting, positionspecific gap penalties and weight matrix choice. Nucleic Acids Res. 22, 4673-4680.

Wise, L., Kappmeyer, L., Mealey, R., Knowles, D., 2013. Review of equine piroplasmosis. J. Vet. Intern. Med. 27, 1334-1346.

Zobba, R., Ardu, M., Niccolini, S., Chessa, B., Manna, L., Cocco, R., Parpaglia, M.L.P., 2008. Clinical and laboratory findings in equine piroplasmosis. J. Eq. Vet. Sci. 28 , 301-308. 